\title{
Pesticidal plants in Africa: a global vision of new biological control products from local uses
}

Philip C. Stevenson ${ }^{1,2 *}$, Murray B. Isman ${ }^{3}$, Steven R. Belmain ${ }^{1}$

\author{
${ }^{1}$ Natural Resources Institute, University of Greenwich, Chatham Maritime, Kent ME4 4TB, \\ United Kingdom \\ ${ }^{2}$ Jodrell Laboratory, Royal Botanic Gardens, Kew, Richmond, Surrey TW9 3AB, United \\ Kingdom \\ ${ }^{3}$ Faculty of Land and Food Systems, University of British Columbia, Vancouver, British \\ Columbia V6T 1Z4, Canada \\ *Corresponding author: Email: p.c.stevenson@gre.ac.uk
}

\begin{abstract}
Botanical insecticides provide a multitude of chemistries for the development of new pest management products. Despite relatively low rates of expansion in botanically based pesticides, regulatory changes in many parts of the world are driving a renaissance for the development of new natural pest control products that are safer for human health and the environment. Africa is arguably the continent with the most to gain from developing natural plant-based pesticides. Hundreds of indigenous and exotic species with pesticidal properties have been reported from Africa through various farmer surveys and subsequent research, many of which have been confirmed to be active against a range of arthropod pests. On-farm use of pesticidal plants, particularly among resource-poor small-holder farmers, is widespread and familiar to many African farmers. Until recently, the pyrethrum industry was dominated by East African production through small holder farmers, showing that non-food cash crop
\end{abstract}


production of pesticidal plants is a realistic prospect in Africa when appropriate entrepreneurial investment and regulatory frameworks are established. This paper reviews the current status of research and commercialisation of pesticidal plant materials or botanically active substances that are used to control pests in Africa and establishes where major gaps lie and formulates a strategy for taking research forward in this area.

Key Words: Botanical Insecticides; Tephrosia; Securidaca; African farming.

\section{Introduction}

Population growth to 9 billion and rising demands for food is increasing pressure on food production, meaning that global food demand will continue to increase for the next 30 years (Godfray et al. 2010). Growing demand for natural resources that underpin production and the urgent need to produce food sustainably will increase pressure on farming, while the impacts of climate change are an additional complicating threat. Severe crop losses from pests and diseases are two of the most important challenges to achieving sustainable global food security (Poppy et al. 2014). Perhaps nowhere on earth is this growing pressure on crops more acute than in Africa where $80 \%$ of food is produced by small holders farming land areas of less than 2 ha, often on marginal degraded lands with little mechanisation or inputs (Stevenson and Belmain, 2016; Sibhatu et al. 2015).

Arguably the most important biological constraint to crop productivity for small holders are insect pests, as these are easily noticed and understood, and their effective control can be monitored with little training. Diseases, soil nutritional deficiencies and nematodes, on the other hand, are less tangible so arguably more challenging to control. Current approaches to insect pest control rely almost exclusively on the use of synthetic pesticides partly because 
alternative biorational approaches are not well-established in the market place (de Bon et al. 2014; Isman, 2006). However, the former can have serious secondary impacts on the environment through misuse and on consumers through persistence on fruit and vegetables (Mutengwe et al. 2016). Pesticides may often be overlooked due to their cost (Sola et al. 2014) or poor efficacy (Midega et al. 2016). Where pesticides are used, large-scale development of resistance and broad spectrum impacts on non-target invertebrates are making it much more difficult to justify and register synthetic pesticides.

The main approach to managing insect pests in agriculture has been the application of synthetic pesticides, and while this has expanded widely during the past few decades in Africa, pesticide expenditure per hectare is still low compared to other regions, and is thus typically less successful than in other parts of the world (Abate, 2000; Oercke and Dehne, 2004). This may be attributable in part to a lack of user training and literacy and the use of outdated and/or adulterated products. Despite the relatively lower use there is broad agreement that current use is potentially harmful owing to the well documented potential negative impacts on users and consumers (Rother, 2013; Williamson et al. 2008) and on the environment including beneficial insects (de Bon et al. 2014; Stevenson and Belmain, 2016). In a recent study in Nigeria, for example, almost $90 \%$ of pesticides being used were classified as highly hazardous or otherwise banned in developed countries while $95 \%$ of farmers had received no training in their use and more than $80 \%$ reported symptoms associated with acute pesticide poisoning (Oluwole and Cheke, 2009). Applications to a single crop are often excessive (Ngowi et al. 2007), while equipment and practises are typically poor, for instance, equipment is not cleaned properly nor do farmers wear any protective clothing (Matthews et al. 2003). To exacerbate this problem there is an absence of instruction, poor literacy and awareness about the dangers of misuse or how to estimate application rates for small land 
areas, little knowledge or information about key pests, diseases and beneficial insects, or the impacts of misuse (Ajayi and Akinnifesi, 2007; de Bon et al. 2014). Major pest insects are also developing resistance to insecticides (Carletto et al. 2010). Besides their hazardous side, synthetic pesticides also represent a significant cost for small holders and may not be widely available particularly in more remote regions, where this review is focussed, increasing the needs for appropriate and reliable alternatives (Belmain and Stevenson, 2001).

Effective alternatives to hazardous synthetic pesticides do exist for small holder farmers in Africa including biological control with fungi and viruses and harnessing natural enemies (Moshi and Matoju, 2017), as well as plant product applications with scope to self-harvest these materials (Grzywacz et al. 2014; Belmain and Stevenson, 2001). Our work over the past decade has focussed on optimising the applications of pesticidal plants in smallholder agriculture in Africa, and we investigated several plant species where knowledge on phytochemistry, mode of action and application were largely absent several of which are included in Table 1. Through this approach, improved applications for pesticidal plant materials have been developed with prospects for commercial development of some plant species currently used by small holder farmers. With this foundation of knowledge, pesticide applications based upon botanically active substances provide a viable alternative to synthetic pesticides. This paper reviews the current status of research and commercialisation of pesticidal plant materials or botanically active substances that are used to control pests in Africa, establishes where major gaps lie, and formulates a strategy for taking research forward in this area.

\section{Botanical insecticides and pesticidal plants in Africa.}


Historically, botanical insecticides were the foundation of pest control until the advent of industrially produced synthetic chemicals; these new compounds eclipsed the efficiency and efficacy of plant chemicals and were produced in bulk as required. Their environmental and health drawbacks, as described above, led to a resurgence of interest in plant chemicals for pest control in the 1980s and 1990s that predicted a new dawn for botanical insecticides, but this fell well short of expectations (Isman, 2006). Only a handful of plant materials are registered for use across the globe and these make up only a small fraction of the technologies used (Isman, 2015). However, recent changes in regulations in Europe have stimulated renewed interest in plant chemistry with a vast increase in research on plant bioactivity as well as new expectations that plant compounds might provide models for new chemistries. More products of increasingly diverse origin are being registered globally (Isman and Grieneisen, 2014, Gerwick and Sparks, 2014).

As commercial products, botanical insecticides have necessarily undergone sophisticated processing that ensures quality and consistency and are sold as a high value products of uniform efficacy and provenance such as those based on neem and pyrethrum (Duke et al. 2010). To remote smallholder farmers in Africa, however, these products differ little from synthetic chemicals in terms of their cost and availability - two important considerations for low input farming (Stevenson and Belmain, 2016). The use of crude plant based materials that are home harvested and prepared using only basic technology is where plants may have most to offer small holders, and in Africa this approach is currently and has been historically widespread (Isman, 2008; Belmain and Stevenson, 2001). To illustrate this point, Kenya once provided up to $80 \%$ of the global demand for pyrethrum, yet pyrethrum products are still only registered for domestic uses on pets in Kenya. Hence, there is little evidence that the experience of commercial production of plant based pesticides has influenced agricultural 
practice of the continent. There is, however, considerable evidence that other pesticidal plants used as crudely produced products among small holder farming communities in Africa (Kamanula et al. 2011, Nyirenda et al. 2011) where increasing scope to optimise pesticidal plant use, but also to identify novel chemistries might provide models for new products (Moshi and Matojou, 2017; Gerwick and Sparks, 2014). Our recent work funded under two EU projects (http://projects.nri.org/options and http://projects.nri.org/adappt) has identified numerous novel chemistries or activities in plants that have been reported as botanical active substances through direct surveys and these add to the growing knowledge about botanically active substances in Africa (Table 1). Securidaca longepedunculata, for example, is an indigenous multiple use small tree species growing across Africa and is reportedly used for the protection of stored grain from weevil damage (Burkhill, 1997). Biological activity in this species is associated with root compounds including methyl salicylate and saponins (Figure 1) that respectively provide rapid repellence or knockdown and longer term efficacy in laboratory based bioassays (Stevenson et al. 2009; Jayasekera et al. 2005; Jayasekera et al. 2002). Similarly, Zanha africana (Radlk.) Exell (Sapindaceae), another indigenous tree species across Southern and Eastern Africa (Swanepoel, 2013), was reported to be a pesticidal plant during our project surveys in Tanzania. Smallholder farmers use ground root bark powder to protect stored beans from bruchids (Mkoga et al. 2004). This genus was already known as a source of medicine (Bruschi et al. 2011) with activity in bark reported against trypanosomiasis (Nibret et al. 2010), bacterial and fungal pathogens (Kambizi and Afolayan, 2001; Fabry et al. 1996), and as an anti-inflammatory (Recio et al. 1995). Despite widespread use, several rare and novel nor-hopanes (Figure 2) were only recently identified in this species (Stevenson et al. 2016) and shown to be responsible for the biological activities reported by farmers. 
While novel chemistries present compelling research avenues, there are many plant species already known in Africa and globally that have recognised biological activities (Table 1), and there is a strong argument for consolidating what knowledge we already have about these species and enabling their exploitation both for small scale and commercial use (Isman and Grieneisen, 2014; Isman 2017). However, even for well-known species there are underlying issues that must be resolved to ensure that their use and exploitation is effective. One particularly pertinent example in Africa is Tephrosia vogelii Hook. f. (Leguminosae). Tephrosia Pers. is a large pantropical genus of more than 350 species, many of which have important traditional uses (Schrire, 2005). Among these species, T. vogelii has been used widely across Africa as a pesticide and a fish poison, but also for improving soil quality (Burkill, 1995; Kamanula et al. 2011; Mafongoya and Kuntashula, 2005; Neuwinger, 2004; Nyirenda et al. 2011; Sileshi et al. 2005; Sirrine et al. 2010). Farmer surveys in Malawi have identified this species as particularly important to farmers in stored product pest control (Nyirenda et al. 2011; Kamanula et al. 2011); however, many farmers reported that this species was ineffective (Stevenson and Belmain, 2016). Chemical analysis of plant material across Malawi identified two distinct chemotypes, one containing rotenoids well known for their biological activity against insects (Isman 2006) and the other characterised by flavones, flavanones and flavonols (Stevenson et al. 2012) (Fig 3). Subsequent bioassays revealed that the pesticidal and insecticidal activities of $T$. vogelii were due to the presence of rotenoids, including deguelin, dehydrodeguelin, rotenone and tephrosin, while the flavonoids in chemotype 2 were inactive (Belmain et al. 2012). Efforts to commercialise this species are facilitated by the fact that it is easily propagated so can be produced in large quantities, while the biologically active compounds occur in all plant parts including the leaves. However, care must be taken to ensure that propagated materials are the correct chemical provenance (chemotype). With a good knowledge of the botanically active compounds and the 
mechanisms of activity it is also possible to better understand chemical variability across time and space, improving harvesting by collecting when the active compounds occur at the highest concentrations (Sarasan et al. 2012; Stevenson et al. 2012). Similarly, where botanically active chemistries are determined for known species the potential to optimise activity through the use of synergists becomes possible and could enhance efficacy and commercial uptake (Tavares et al, 2016).

\section{Safety and exposure to toxic plant compounds}

In industrialised nations stored product pests have largely been consigned to history with advanced technology-based storage solutions such as the use of ozone or radio frequency heating (Hou et al. 2016; Isikber and Athanassiou, 2015). Current losses to storage pests in developing countries including most African nations are estimated to be around 17\% (http://www.aphlis.net) so securing harvested agricultural produce is arguably the greatest priority of pest management research and development particularly in marginal agriculture typical of Africa (Midega et al. 2016). Reflecting this priority, many indigenous uses of plants in Africa are to protect stored products (Kamanula et al. 2011). However, protecting stored products risks exposure of consumers to potentially harmful plant chemicals. A natural plant chemical is not necessarily a safe one. Indeed, some of the most toxic compounds known are of plant origin, such as aconitine, which occurs in species from the genus Aconitum where it provides defensive compounds against nectar robbers (Barlow et al., 2017) but can have life threatening consequences if ingested by mammals even in very small quantities (Kolev et al. 1996). Pesticidal plants are by definition toxic otherwise they would not kill the pest and this needs to be considered in outreach and promotion of these low tech methods of pest control. For example, many plant species known in Africa for their insecticidal properties are also reported to be used for poisoning fish (Neuwinger 2004) 
including many species in the Leguminosae. The toxicity of these species is often associated with saponins and rotenoids and many of these species have bioactivity against pest insects or are used in pest management, including Tephrosia vogelii (Stevenson et al. 2012; Belmain et al. 2012), Euphorbia tirucalli L. (Euphorbiaceae) and Neoratanenia mitis (A. Rich.) Verdc. (Leguminiosae) (Mulungu et al. 2011), Balanites aegyptiaca (L.) Delile (Zygophyllaceae) (Chapagain et al. 2007) and the fish bean Bobgunnia (syn. Swartzia) madagascariensis (Desv.) J.H.Kirkbr. \& Wiersema Leguminosae (Muyobela et al. 2016, Sarasan et al. 2011; Stevenson et al. 2009). Consequently great care must be taken in deploying plants for pest management that have potential toxicity to aquatic fauna; in some regions, their use may need to be restricted in proximity to waterways.

Nonetheless expected concentrations of plant toxins to which farmers are likely to be exposed in crude plant materials and their extracts is typically very low, and the likelihood of acute toxicity from handling plants is substantially lower than the risk from handling synthetic pesticides (Coats, 1994; Isman, 2006). As mentioned above, the biological activity of Tephrosia vogelii, for example, is mediated by rotenoids, primarily deguelin, tephrosin and rotenone (Belmain et al. 2102). The oral LC50 for rotenone is reported to be in the range 132 to $1,500 \mathrm{mg} / \mathrm{kg}$ in rats. To put this in context, the LC50 in rats for caffeine is $190 \mathrm{mg} / \mathrm{kg}$. For humans, who are considered to be fairly susceptible to rotenone, an oral lethal dose of the pure compound is estimated to be from 300 to $500 \mathrm{mg} / \mathrm{kg}$ (Kidd and James, 1991). These rotenoids occur at around $1.0 \mathrm{mg} / \mathrm{g}$ in dry plant material so for a $70 \mathrm{~kg}$ human to be exposed to a potentially lethal dose of rotenoids from Tephrosia would require consumption of over $20 \mathrm{~kg}$ of dry leaves. However, inhalation of the dust presents much increased risk, so appropriate safety equipment should be used particularly when processing and handling ground, powdered plant materials. It is notable that, although previously registered, 
rotenone is no longer approved for use as an insecticide in Europe under regulation (EC) No. 540/2011 although confusingly it is still listed under the acceptable organic treatments under regulations (EC) No. 834/2007 and No. 889/2008. The effects of rotenone against beneficial insects is not adequately determined and deserves further study.

\section{Compatibility of pesticidal plants with other pest management strategies}

Pesticidal plants are often reported to be less environmentally harmful particularly with respect to beneficial insects (Akhtar et al. 2008; Devanand and Rani, 2008 Rathi and Gopalakrishnan, 2006). Yet there is surprisingly little research invested in determining the impacts of botanically active substance on important ecosystem services provided by invertebrates. More evidence of lower impacts might leverage greater uptake and demonstrate commercially relevant advantages over synthetic products that typically have a broad spectrum of activity and therefore little selectivity favouring natural enemies and pollinators. Formulations of azadirachtin, for example, may be less toxic to lacewings than pests but are not harmless while azadirachtin was previously shown to be more toxic to honeybees than other insects (Medina et al. 2004; Naumann and Isman, 1996). Plant compounds are often more selective in activity. While selectivity could be a disadvantage where broad spectrum efficacy is required, it could be an advantage by reducing impacts on beneficial insects. Field trials, for example, have shown that the use of Neem extracts to control insects on Canola did not deter honeybees from visiting flowers and pollinating (Naumann and Isman, 1996). Elsewhere grayanotoxin 1, is a naturally occurring defence compound in Rhododendron simsii Planch. (Ericaceae) (Scott-Brown et al. 2016) but occurs in nectar of Rhododendrons including $R$. ponticum L. (Ericaceae) where it is not harmful to bumblebees (Bombus spp.) that are the primary pollinator of this genus (Tiedeken et al. 2016). Efforts to develop botanical pesticides based on related grayanoid diterpenes have 
shown considerable potential in controlling Pieris rapae L. (Lepidoptera: Pieridae) (Zhong et al. 2006) where their selective activity could lead to development of effective pesticides with lower impacts on pollinators. Thus testing botanically active substances should be a research cornerstone in the development of plant based pesticides in Africa. Recent studies comparing the efficacy of crudely prepared pesticidal plants and synthetics have enlightened this issue. Amoabeng et al. (2013) evaluated the pesticidal efficacy of water extracts of 9 indigenous and invasive herbaceous plant species used as pesticides by small holders in Ghana on cabbage pests. All provided a good level of control of Plutella xylostella L. (Lepidoptera: Plutellidae) and Brevicoryne brassica (Hemiptera: Aphidae) compared to untreated fields and resulted in equivalent yields to the synthetic pesticide Attack - a combination of permethrin and pirimiphos methyl. Importantly the effect of the plant extracts on three beneficial arthropod groups: Syrphidae (hoverflies), Araneae (spiders) and Coccinellidae (lady beetles) was lower than that of the synthetic pesticide, suggesting that the benefits of plant pesticides cascade to the third trophic level. In another recent field study, Mkenda et al. (2015a) showed that four pesticidal plant species were able to control a range of pests attacking Phaseolus vulgaris L. (Leguminosae) (common beans) but were also less harmful to beneficial insects compared to a synthetic pesticide treatment. Further work is needed to determine the underlying mechanisms that reduce impacts on beneficial insects and understand if this is due to selective toxicity or potentially to the UV labile nature of plant compounds breaking down more quickly so having lower persistence. The latter might mean more frequent sprays are required and could influence the economics of using pesticidal plants but recent evidence suggests pesticidal plants are as if not more economically viable than synthetic pesticides (Amoabeng et al. 2014; Mkenda et al. 2015b).

\section{Commercial potential and future prospects}


A resurgence of interest in botanically active substances suggests renewed potential for their commercialisation (Isman and Grieneisen, 2014; Isman, 2015) perhaps stimulated by ever increasing regulatory pressure on commercial synthetic insecticides and increasing public interest in food produced using environmentally benign approaches (Sola et al. 2014). The global perspective on this topic is covered elsewhere in this issue (Isman, 2017); however, here we looked briefly at the issues facing Africa. Commercialisation of plants as pesticides has perhaps no better home than Africa since at one point the global pyrethrum sector was heavily reliant on plants produced commercially in East Africa, particularly Kenya. Where once Kenya supplied $80 \%$ of global demand it now provides a fraction of that (Wandahwa et al. 1996). The pyrethrum sector once employed tens of thousands of small holders across East Africa but collapsed largely through poor governance and government control (Francis and Amuyunzu-Nyamongo, 2008). Pyrethrum production is once again growing in East Africa and provides a blueprint for commercialising other species, such as Tephrosia vogelli, as long as the technical support for efficacy and safety can be improved.

Recent liberalisation of the pyrethrum sector in East Africa may provide new opportunities for this and other plant species (Sibanda, 2015). Recently industrialized nations including India, China and Brazil may be setting an example of how to exploit the commercial potential of plants, but this requires changes in regulatory policy to enable more widespread commercialisation of plant based products as pesticides. Wide-scale use of plants for pest control remains limited despite the historic precedent of pyrethrum. The reasons for limited use in Africa are complex and maybe due to insufficient information on efficacy and safety, inconsistent efficacy of plant materials, the expense and process of registration, and a poorly developed conventional pesticides sector (Sola et al. 2014). Regulations and protocols for commercialisation may benefit from review and relaxation of some of the stringent rules 
designed for synthetic compounds if Africa is to exploit fully its potential, indigenous knowledge and current small holder use of pesticidal plants. It is worth noting that often mixtures of compounds in botanical pesticides have synergistic effects (Tak and Isman, 2017a and b) so mechanisms to facilitate registration of chemically complex plant products may enhance their use. But large scale propagation is also critical and is perhaps the biggest single constraint to the commercialisation of pesticidal plants. Recent advances have improved the scope for propagation of indigenous plant species in Africa that are otherwise increasingly rare or local (Anjarwalla et al. 2016). Africa has great potential to broaden the diversity of its non-food agricultural sector and could provide poor farmers with a new livelihood opportunity, while impacting reliance on the import of synthetic pesticides, but this requires good cooperation between African entrepreneurs, policy makers and scientists.

\section{Where next for pesticidal plants in Africa?}

The diversity of plants species and the abundance of examples of biologically active plants from Africa suggest it is a land of plenty (Table 1). However specific areas of research, outreach and uptake must be addressed to maximise this potential. Despite the surge of interest in plant-derived pesticides over the last decade, including much research from Africa (Isman and Grieneisen, 2014; Isman, 2015) surprisingly little time is invested in assessing efficacy under field conditions. This needs greater attention and may highlight added benefits. For example, from the handful of examples, recent field trials of pesticidal plants on beans and cabbage indicate that some plant extracts are as effective as synthetic pesticides, but the impact on beneficial insects such as predators is lower (Amoabeng et al. 2013; Mkenda et al. 2015b). These approaches can also help to determine the economic benefits of using pesticidal plants over conventional products (Amoabeng et al. 2014; Mkenda et al. 2015b). This kind of evidence is critical to convince policy makers to support plant based 
pest management strategies but also to convince farmers of the financial benefit of using plants compared to conventional insecticides.

Pest management that relies less on pesticides is likely to increasingly rely on beneficial insects and this ecosystem service is biodiversity dependent (Losey and Vaughan, 2006). Some plant species grown adjacent to farmers fields could provide forage and refuge for beneficial insects, and if grown intentionally, could supplement natural pest control. For example, sesame grown around paddy fields in East Asia supports herbivorous leafhoppers which, in turn, support parasitic wasps that can build up numbers to meaningfully control brown plant hopper (Nilaparvata lugens), the main insect pest of rice (Gurr et al. 2016). If field margin plants were pesticidal but also provided forage and refuge for beneficial insects these might provide a compelling outreach strategy for small holders. It might also provide opportunities to grow commercially relevant quantities to sell.

Much published work is not repeatable for various reasons and adds little to our knowledge about mechanisms, efficacy or scope to use plant materials in pest management. Perhaps most critically is the lack of meaningful chemical data reported alongside efficacy trials as well as a surprising lack of positive controls in experiments (Isman and Grieneisen, 2014). There is also merit in considering whether research efforts should be invested in discovering new botanically active species or focus more on optimising the use and application of species and plant chemistries that are already well known (Table 1). New approaches to exploit plant chemicals might have greater impact than starting from scratch. For example, combining biological pest control technologies with insecticidal plants could be a way to reinvent their use. Insecticidal microorganisms are typically slow acting (Lacey et al. 2015; Ortiz-Urquiza et al. 2015) whereas botanical insecticides such as pyrethrum can have a quick knockdown 
but have poor persistence. When combined they may ameliorate the shortcomings of each other (Mazariegos-Hurtado, 2016). Also, there may be some worth in evaluating combinations of plants to determine if these may have improved efficacy. Commercial products that combine pyrethrum and neem and other mixtures of phytochemicals have been used against mosquitos (Shaalan et al. 2005) while botanical insecticides are already commercialised in China, India and Korea that contain mixtures of two or more plant extracts (Isman, 2014). More research could be invested in combinations of plants against agricultural and horticultural pests, looking for potential synergistic effects or complementary modes of action.

\section{Conclusions}

Africa is arguably the continent with the most to gain from developing natural plant-based pesticides. Hundreds of indigenous and exotic species with pesticidal properties have been reported from Africa through various farmer surveys, many of which have been confirmed to be active against a range of arthropod pests. On-farm use of pesticidal plants, particularly among resource-poor smallholder farmers, is widespread and familiar to many African farmers. Until quite recently, the pyrethrum industry was dominated by East African production through small holder farmers, showing that non-food cash crop production of pesticidal plants is possible in Africa when appropriate entrepreneurial and regulatory frameworks are established. It remains to be seen whether African nations can build on their indigenous knowledge and commercial expertise to overcome the hurdles to develop the next generation of new cash crops for botanically-based pest management.

\section{Acknowledgments}


Funding was obtained from a European Union 9th European Development Fund grant from the African Caribbean and Pacific Science and Technology Programme (FED/2013/329-272) http://www.acp-st.eu/ and a McKnight Foundation grant (Grant No: 13-335) https://www.mcknight.org/grant-programs/international/collaborative-crop-research. The funders had no role in decision to publish or in the preparation of the manuscript. 


\section{References}

Abate, T., van Huis, A., Ampofo, J.K.O., 2000. Pest management strategies in traditional agriculture: an African perspective. Ann. Rev. Entomol. 45, 631-659.

Ajayi O.C., Akinnifesi, F.K. 2007. Farmers' understanding of pesticide safety labels and field spraying practices: a case study of cotton farmers in northern Cote d'Ivoire. Sci. Res. Essays. 2, 204-210.

Akhtar, Y., Yeoung, Y.R., Isman, M.B., 2008. Comparative bioactivity of selected extracts from Meliaceae and some commercial botanical insecticides against two noctuid caterpillars, Trichoplusia ni and Pseudaletia unipuncta. Phytochem. Rev. 7, 77-88.

Amoabeng, B.W., Gurr, G.M. Gitau, C.W., Nicol, H.I., Munyakazi, L. Stevenson, P.C., 2013. Tri-trophic insecticidal effects of African plants against cabbage pests. PLoS One. 8, e78651.

Amoabeng, B.W., Gurr, G.M. Gitau, C.W., Stevenson, P.C. 2014. Cost: benefit analysis of botanical insecticide use in cabbage: implications for smallholder farmers in developing countries. Crop Prot. 57, 71-76.

Anjarwalla, P., Belmain, S., Sola, P., Jamnadass, R., Stevenson, P.C., 2016. Handbook on Pesticidal Plants. World Agroforestry Centre (ICRAF), Nairobi, Kenya. 
Barlow, S., Wright G.A., Ma, C., Barberis, M., Farrell, I.W., Marr, E.M., Brankin, A., Pavlik, B.M., Stevenson, P.C. 2017. Distasteful nectar deters floral robbery. Curr. Biol. http://dx.doi.org/10.1016/j.cub.2017.07.012.

Belmain, S.R. \& Stevenson, P.C., 2001. Ethnobotanicals in Ghana: reviving and modernising an age-old practise. Pesticide Outlook 6, 233-238.

Belmain, S.R., Amoah, B.A., Nyirenda, S.P., Kamanula, J.F., Stevenson, P.C., 2012. Highly Variable Insect Control Efficacy of Tephrosia vogelii Chemotypes. J Agric Fd Chem. 60, $10055-10063$.

Belmain, S.R., Neal, G.E., Ray, D.E., Golob, P., 2001. Insecticidal and vertebrate toxicity associated with ethnobotanicals used as post-harvest protectants in Ghana. Food Chem Toxicol. 39, 287-291.

Borel, C., Hostettmann, K., 1987. Molluscicidal saponins from Swartzia madagarscariensis Desveaux, Helv Chim Acta. 70, 570-576.

Bossou, A.D., Mangelinckx, S., Yedomonhan, H., Boko, P.M., Akogbeto, M.C., De Kimpe, R., Avessi, F. Sohounhloue, D.C.K., 2013. Chemical composition and insecticidal activity of plant essential oils from Benin against Anopheles gambiae (Giles) Parasite Vector. 6, 337. 
Bruschi, P., Morganti, M., Mancini, M., Signorini, M.A., 2011. Traditional healers and laypeople: a qualitative and quantitative approach to local knowledge on medicinal plants in Muda (Mozambique). J. Ethnopharmacol. 138, 543-563.

Burkill, H. M., 1997. The Useful Plants of Tropical West Africa; Royal Botanic Gardens: Kew, U.K. Vol. 4, pp 454-458.

Burkill, H. M., 1995. The Useful Plants of West Tropical Africa, vol. 3, second ed. Royal Botanic Gardens, Kew, pp. 460-462.

Carletto, J., Martin, T., Vanlerberghe-Masutti, F., Brévault, T., 2010. Insecticide resistance traits differ among genotypes from different host races in the aphid Aphis gossypii. Pest Manag. Sci. 66, 301-307.

Chapagaina, B.P., Saharana, V., Wiesman, Z., 2008. Larvicidal activity of saponins from Balanites aegyptiaca callus against Aedes aegypti mosquito. Bioresour. Technol. 99, 11651168.

Coats, J.R., 1994. Risks From Natural Versus Synthetic Insecticides. Annu. Rev. Entomol. $39,489-515$.

de Bon, H., Huat, J., Parrot, L. Sinzogan, A., Martin, T., Malézieux, E., Vayssières, J.F., 2014. Pesticide risks from fruit and vegetable pest management by small farmers in subSaharan Africa. A review. Agron. Sustain. Dev. 34, 723-736. 
Devanand, P., Rani, P.U., 2008. Biological potency of certain plant extracts in management of two lepidopteran pests of Ricinus communis L. J. Biopesticides. 1, 170-176.

Duke, S.O., Cantrell, C.L., Meepagala, K.M., Wedge, D.E., Tabanca, N., Schrader, K.K., 2010. Natural Toxins for Use in Pest Management. Toxins 2, 1943-1962

Elsayed, G. 2011. Insecticidal effect of plant extracts on two termite species. Archives of Phytopathology and Plant Protection, 44, 356-361.

Fabry, W., Okemo, P., Ansorg, R., 1996. Fungistatic and fungicidal activity of East African medicinal plants. Mycoses 39, 67-70.

Francis, P., Amuyunzu-Nyamongo, M., 2008. Bitter Harvest: The Social Costs of State Failure in Rural Kenya, in: Moser, C., Dani, A.A. (Eds.), Assets, Livelihoods and Social Policy. The World Bank, Washington DC, USA, pp. 249-235.

Gerwick, B. C., \& Sparks, T. C., 2014. Natural products for pest control: An analysis of their role, value and future. Pest Manag. Sci. 70, 1169-1185.

Godfray, H.C.J., Beddington, J.R., Crute, I.R., Haddad, L., Lawrence, D., Muir, J.F., Pretty, J., Robinson, S., Thomas, S.M. and Toulmin, C., 2010. Food Security: The Challenge of Feeding 9 Billion People, Science 327, 812-817. 
Green, P.W.C., Ndakidemi, P., Farrell, I., Belmain, S.R. Stevenson, P.C., 2017. Compounds contributing to the insecticidal activity of extracts from Tithonia diversifolia and Vernonia amygdalina. Ind Crop Prod.

Grzywacz, D., Stevenson, P.C., Belmain, S.R., Wilson, K., 2014. The Use of Indigenous Ecological Resources for Pest Control in Africa, Food Sec. 6, 71-86.

Gurr, G.M., Lu, Z., Zheng, X., Xu, H., Zhu, P. Chen, G., Yao, X., Cheng, J., Zhu, Z., Catindig, J.D., Villareal, S., Chien, H.V., Cuong, L.Q., Channoo, C., Chengwattana, N., Lan, L.P., Hai, L.H., Chaiwong, J., Nicol, H.I., Perovic, D.J., Wratten, S.D., Heong, K.L., 2016. Multi-country evidence that crop diversification promotes ecological intensification of agriculture, Nature Plants 2, 16014.

Hou, L., Johnson, J.A., Wang, S., 2016. Radio frequency heating for postharvest control of pests in agricultural products: A review. Postharvest Biol. Technol. 113, 106-118.

Isikber, A.A., Athanassiou, C.G., 2015. The use of ozone gas for the control of insects and micro-organisms in stored products. J. Stored Prod. Res. 64, 139-145.

Isman, M.B., 2006. Botanical Insecticides in an increasingly regulated world. Ann. Rev. Entomol. 51, 45-66.

Isman, M.B., 2008. Botanical insecticides: for richer, for poorer. Pest Manag. Sci. 64, 8-11. 
Isman, M.B., Grieneisen, M.L., 2014. Botanical insecticide research: many publications, limited useful data. Trends Plant Sci.19, 140-145.

Isman, M.B. 2014. Botanical Insecticides: A Global Perspective. in Aaron D. Gross, A.D., Coats, J.R., Duke, S.O., Seiber, J.N. (Eds.) Biopesticides: State of the Art and Future Opportunities. ACS Symposium Series, Vol. 1172, Chapter 2, pp 21-30. American Chemical Society DOI: 10.1021/bk-2014-1172.ch002

Isman, M.B., 2015. A renaissance for botanical insecticides? Pest Manag. Sci. 71, 15871590.

Isman, M.B., 2017. Bridging the gap: moving botanical insecticides from the laboratory to the field. Ind Crop Pro. doi.org/10.1016/j.indcrop.2017.07.012.

Jayasekera, T., Stevenson, P.C., Hall, D.R. and Belmain, S.R., 2005. Effect of Volatile Constituents from Securidaca longepedunculata On Stored Grain Insect Pests. J. Chem. Ecol. 31, $303-313$.

Jayasekera, T., Stevenson, P.C., Belmain, S.R. and Hall, D.R., 2002. Methylsalicylate isomers in the roots of Securidaca longepedunculata, J. Mass Spectrom. 37, 577-580.

Joseph, C.C., Ndoile, M.M., Malima, R.C., Nkunya, M.H.H., 2004. Larvicidal and mosquitocidal extracts, a coumarin, isoflavonoids and pterocarpans from Neorautanenia mitis. T Roy Soc Trop Med H. 98, 451-455. 
Kamanula JF, Sileshi, G., Belmain, S.R., Sola, P., Mvumi, B., Nyirenda, G.K.C., Nyirenda, S.P.N., Stevenson, P.C., 2011. Farmers' Pest management practices and pesticidal plant use for protection of stored maize and beans in Southern Africa. Int. J. Pest Manage. 57, 41-49.

Kamanula, J.F., Belmain, S.R., Hall, D.R., Farman, D.I., Goyder, D.J., Mvumi, B.M., Masumbu, F.F., Stevenson, P.C., 2017. Chemical variation and insecticidal activity of Lippia javanica (Burm. F.) Spreng essential oil against Sitophilus zeamais Motschulsky. Ind Crop Prod. doi:10.1016/j.indcrop.2017.06.036.

Kambizi, L., Afolayan, A.J., 2001. An ethnobotanical study of plants used for the treatment of sexually transmitted diseases (njovhera) in Guruve District, Zimbabwe. J. Ethnopharmacol. 77, 123-123.

Kidd, H., James, D.R., 1991. The Agrochemicals Handbook. 1991. The Royal Society of Chemistry. Cambridge, England.

Kimutai, A., Ngeiywa, N., Mulaa, M., Niagi, P.G.N., Ingonga, J., Nyamwamu, L.B., Ombati, C., Ngumbi, P., 2017. Repellent effects of the essential oils of Cymbopogon citratus and Tagetes minuta on the sandfly, Phlebotomus duboscqi. BMC Research Notes. 10, 98.

Kolev, S.T., Leman, P., Kite, G.C, Stevenson, P.C., Shaw, D., Murray, V.S.G., 1996. Toxicity following accidental ingestion of Aconitum containing Chinese remedy. Hum Exp. Toxicol. 15, 839-842. 
Lacey, L.A., Grzywacz, D., Shapiro-Ilan, D.I., Frutos, R., Brownbridge, M., Goettel, M.S., 2015. Insect pathogens as biological control agents: Back to the future. J. Invertebr. Pathol. $132,1-41$.

Losey, J.A., Vaughan, M., 2006. The economic value of ecological services provided by insects. Bioscience 56, 311-323.

Madzimure, J., Nyahangare, E.T., Hove, T., Hamudikuwanda, H., Belmain, S.R. Stevenson, P.C., Mvumi, B.M., 2013. Acaricidal efficacy of Strychnos spinosa (Lam.) and Solanum incanum fruit-extracts against cattle ticks. Trop. Anim. Health Pro. 45, 1341-1347.

Mafongoya, P. L., Kuntashula, E., 2005. Participatory evaluation of Tephrosia species and provenances for soil fertility improvement and other uses using farmer criteria in eastern Zambia. Exp. Agric. 41, 69-80.

Matthews, G., Wiles, T., Baleguel, P., 2003. A survey of pesticide application in Cameroon. Crop Prot. 22, 707-714.

Mavundza, E.J., Maharaj, R., Chukwujekwu, J.C., Finnie, J. F., and Van Staden, J., 2013. Larvicidal activity against Anopheles arabiensis of 10 South African plants that are traditionally used as mosquito repellents, S. Afr. J. Bot., 88, 86-89. 
Mazariegos-Hurtado, L.A., 2016. Pest control formulation composed of Beauveria bassiana, cold pressed neem oil and refined pyrethrum extract, and methods of making and using same. Patent No. WO 2016071891 A1

Medina, P., Budia, F., Del Estal, P., Vinuela, E., 2004. Influence of Azadirachtin, a Botanical Insecticide, on Chrysoperla carnea (Stephens) Reproduction: Toxicity and Ultrastructural Approach. J Econ Entomol. 97, 43-50.

Mengistu, G., Hoste, H., Karonene, M., Salminen, J. -P., Hendriks, W. H., Pellikaan, W. F., 2017. The in vitro anthelmintic properties of browse plant species against Haemonchus contortus is determined by the polyphenol content and composition. Vet Parasitol. 237, 110116.

Midega, C. A. O., Murage, A.W., Pittchar, J.O., Khan, Z.R., 2016. Managing storage pests of maize: Farmers' knowledge, perceptions and practices in western Kenya. Crop Prot. 90, 142-149.

Mkenda, P.A., Stevenson, P.C., Ndakidemi, P., Farman, D.I. , Belmain, S.R., 2015a. Contact and fumigant toxicity of five pesticidal plants against Callosobruchus maculatus in stored cowpea (Vigna unguiculata). Int. J. Pest Manage. 35, 172-184.

Mkenda, P.A., Mwanauta' R., Stevenson, P.C. Ndakidemi' P., Mtei, K., Belmain, S.R., 2015b. Field margin weeds provide economically viable and environmentally benign pest control compared to synthetic pesticides, PLoS One, 10, e0143530 
Mkindi, A., Mpumi, N., Tembo, Y., Stevenson, P.C., Ndakidemi, P.A., Mtei, K., Machunda, R., Belmain, S.R., 2017. Invasive weeds with pesticidal properties as potential new crops. Ind Crop Prod. doi:10.1016/j.indcrop.2017.06.002.

Mkoga, Z.J., Shetto, R.M., Mkomwa, S., Mwakimbwala, R., Kabungo, D.A., Ndegeulaya, D., 2004. Efficacy of botanical insecticides on Sitophilus species on maize in the Southern Highlands of Tanzania. Tanzania Agricultural Training Newsletter. 19, 6-8.

Moshi, A. P., Matoju, I., 2017. The status of research on and application of biopesticides in Tanzania. Crop Prot. 92, 16-28.

Mulungu, L. S., Ndilahomba, B., Nyange, C. J., Mwatawala, M. W., Mwalilino, J. K., Joseph, C. C., Mgina, C. A., 2011. Efficacy of Chrysanthemum cinerariaefolium, Neorautanenia mitis and Gnidia kraussiana against Larger Grain Borer (Prostephanus truncatus Horn) and Maize Weevil (Sitophilus zeamays Motschulsky) on Maize (Zea mays L.) Grain Seeds. J Entomol 8, 81-87.

Mutengwe, M.T., Chidamba, L., Korsten, L., 2016. Monitoring Pesticide Residues in Fruits and Vegetables at Two of the Biggest Fresh Produce Markets in Africa. J Food Protect. 79, 1938-1945.

Muyobela, J., Nkunika, P.O.Y., Mwase, E.T., 2016. In vitro acaricidal activity of Bobgunnia madagascariensis Desv. against Amblyomma variegatum (Fabricius) (Acari: Ixodidae). Trop Anim Health Pro. 48, 625-631. 
Mwine , J., Van Damme, P., Jumbe, F., 2010. Evaluation of larvicidal properties of the latex of Euphorbia tirucalli L. (Euphorbiaceae) against larvae of Anopheles mosquitoes. J Med Plants Res. 4, 1954-1959

Naumann, K., Isman, M.B., 1996, Toxicity of a neem (Azadirachta indica A. Juss) insecticide to larval honey bees. Am Bee J. 136, 518-520.

Neuwinger, H. D., 2004. Plants used for poison fishing in tropical Africa. Toxicon 44, 417430.

Ngowi, A.V.F., Mbise, T.J., Ijani, A.S.M., London, L., AJayi, O.C., 2007. Smallholder vegetable farmers in Northern Tanzania: Pesticides use practices, perceptions, cost and health effects. Crop Prot. 26, 1617-1624.

Nibret, E., Ashour, M.L., Rubanza, C.D., Wink, M., 2010. Screening of some Tanzanian medicinal plants for their trypanocidal and cytotoxic activities. Phytother. Res. 24, 945-947

Nyirenda, S.P.N. Sileshi, G., Belmain, S.R., Kamanula, J.F., Mvumi, B., Sola, P., Nyirenda, G.K.C. Stevenson, P.C., 2011. Farmers' Ethno-Ecological Knowledge of Vegetable Pests and their Management Using Pesticidal Plants in Northern Malawi and Eastern Zambia. Afr. J. Agric. Res. 6, 1525-1537.

Nyahangare, E.T., Hove, T., Mvumi, B.M., Hamudikuwanda, H., Belmain, S.R., Madzimure J., Stevenson, P.C., 2012. Acute mammalian toxicity of four pesticidal plants, J Med Plants Res. 6, 2674-2680. 
Oercke, E.C., Dehne, H.W., 2004. Safeguarding production-losses in major crops and the role of crop protection. Crop Prot. 23, 275-285.

Oluwole, O., Cheke, R.A., 2009. Health and environmental impacts of pesticide use practices: a case study of farmers in Ekiti State, Nigeria. Int. J. Agr. Sustain. 7, 153163.

Ortiz-Urquiza, A., Luo, Z., Keyhani, N.O., 2015. Improving mycoinsecticides for insect biological control. Appl. Microbiol. Biotechnol. 99, 1057-1068.

Perich, M.J., Wells, C., Bertsch, W., Tredway, K.E., 1995. Isolation of the insecticidal components of Tagetes minuta (Compositae) against mosquito Larvae and adults. J Am Mosquito Contr. 11, 307-310.

Poppy, G.M., Jepson, P.C., Pickett, J.A., Birkett, M.A., 2014. Achieving food and environmental security: new approaches to close the gap. Phil. Trans. R. Soc. B, 369, 20120272.

Rathi, J., Gopalakrishnan, S., 2006. Insecticidal activity of aerial parts of Synedrella nodiflora Gaertn (Compositae) on Spodoptera litura (Fab.). J Central European Agric. 6, $223-228$ 
Recio, M.C., Giner, R.M., Manez, S., Rios, J.L., Marston, A., Hostettmann, K., 1995. Screening of tropical medicinal plants for anti-inflammatory activity. Phytother. Res. 9, 571574.

Rioba, N.B., Stevenson, P.C., 2017. Ageratum conyzoides L. for the management of pests and diseases by small holder farmers. Ind Crop Prod. doi.org/10.1016/j.indcrop.2017.06.068

Rother, H.A., 2013. Falling Through the Regulatory Cracks: Street Selling of Pesticides and Poisoning among Urban Youth in South Africa. Int. J. Occup. Environ. Health 16, 183-194

Sarasan, V., Kite G.C., Sileshi, G.W., Stevenson P.C., 2011. The application of Phytochemistry and in vitro tools to the sustainable utilisation of medicinal and pesticidal plants for income generation and poverty alleviation. Plant Cell Rep. 30, 1163-1172.

Schrire, B. D., 2005. Tribe Millettieae. In: Lewis, G., Schrire, B., Mackinder, B., Lock, M. (Eds), Legumes of the World. Royal Botanic Gardens, Kew, pp. 367-387 (Tephrosia on p. 386).

Scott-Brown, A., Gregory, T., Farrell, I., Stevenson, P.C., 2016. Leaf trichomes and grayanotoxin 1 mediate plant defense against glasshouse thrips in Rhododendron simsii. Funct Plant Biol. 43, 1170-1182

Shaalan, E. A-S, Canyon, D.V., Younes, M.W.F., Abdel-Wahab, H., Mansour, A-H., 2005. Synergistic efficacy of botanical blends with and without synthetic insecticides against Aedes aegypti and Culex annulirostris mosquitoes. J Vector Ecol. 30, 284-288. 
Sibanda, O.S., 2015. Trade liberalisation and its impact on food security in Sub-Saharan Africa. Int. J. Public Law Policy 5, 92.

Sibhatu, K.T., Krishna, V. V, Qaim, M., 2015. Production diversity and dietary diversity in smallholder farm households. Proc. Natl. Acad. Sci. 112, 10657-62.

Sileshi, G., Mafongoya, P.L., Kwesiga, F., Nkunika, P., 2005. Termite damage to maize grown in agroforestry systems, traditional fallows and monoculture on nitrogen-limited soils in eastern Zambia. Agric. For. Entomol. 7, 61-69.

Sirrine, D., Shennan, C., Sirrine, J. R., 2010. Comparing agroforestry systems' ex ante adoption potential and ex post adoption: on-farm participatory research from southern Malawi. Agroforestry Syst. 79, 253-266.

Sola, P., Mvumi, B.M., Ogendo, J.O., Mponda, O., Kamanula, J.F., Nyirenda, S.P., Belmain S.R. and Stevenson. P.C., 2014. Botanical pesticide production, trade and regulatory mechanisms in sub-Saharan Africa: making a case for plant-based pesticidal products. Food Secur. 6, 369-384.

Stella Nerio, L., Olivero-Verbel, J., Stashenko, E., 2010. Repellent activity of essential oils: A review. Bioresource Technol. 101, 372-378. 
Stevenson, P.C. Jayasekera, T.K., Belmain, S.R., Veitch, N.C., 2009. Bisdesmosidic saponins from Securidaca longepedunculata (Polygalaceae) with deterrent and toxic properties to Coleopteran storage pests. J Agric Fd Chem. 57, 8860-8867.

Stevenson, P.C., Nyirenda, S.P. and Veitch, N.C., 2010. Highly glycosylated flavonoid glycosides from Bobgunnia madagascariensis. Tet Lett. 51, 4727-4730.

Stevenson, P.C. Kite G.C., Lewis G.P., Nyirenda S.P., Forest F. Belmain, S.R, Sileshi, G. Veitch, N.C., 2012. Distinct chemotypes of Tephrosia vogelii and implications for their use in pest control and soil enrichment. Phytochemistry 78, 135-146.

Stevenson, P.C., Green, P.W.C., Veitch, N.C., Farrell, I., Kusolwa, P. Belmain, S.R., 2016. Nor-Hopanes explain pest control activity of Zanha africana root bark. Phytochemistry 123, $25-32$.

Stevenson P.C., and Belmain S.R., 2016. Pesticidal Plants in African Agriculture: Local uses and global perspectives. Outlook on Pest Management 10, 226-229.

Swanepoel, W., 2013. Sapindaceae Zanha africana, a new distribution record for Namibia. Bothalia 43, 88-89.

Tak, J.H. and Isman, M.B., 2017a. Penetration-enhancement underlies synergy of plant essential oil terpenoids as insecticides in the cabbage looper, Trichoplusia ni. Sci Rep. 7, 42432. 
Tak, J.H. and Isman, M.B., 2017b. Enhanced cuticular penetration as the mechanism of synergy for the major constituents of thyme essential oil in the cabbage looper, Trichoplusia ni. Ind Crop Prod. 101, 29-35.

Tavares, W.S., Akthar, Y., Gonçalves, G.L.P., Zanuncio, J.C., Isman, M.B., 2016. Turmeric powder and its derivatives from Curcuma longa rhizomes: Insecticidal effects on cabbage looper and the role of synergists. Sci Rep. 6, 34093.

Tiedeken E-J., Egan, P.A., Stevenson, P.C., Wright, G.A., Brown, M.J.F., Power, E.F., Farrell., I., Matthews, S.M., Stout, J.C., 2016. Nectar chemistry modulates the impact of invasive plant species on native pollinators. Func Ecol. 30, 885-893.

Verma, R.S., Padalia, R.C., Goswami, P. Verma, S.K., Chauhan, A. Darokar, M.P., 2016. Chemical Composition and Antibacterial Activity of Bidens pilosa. Chem Nat Comp. 52, $340-341$

Wandahwa, P., Van Ranst, E., Van Damme, P., 1996. Pyrethrum (Chrysanthemum cinerariaefolium Vis.) cultivation in West Kenya: origin, ecological conditions and management. Ind Crop Prod. 5, 307-322.

Williamson, S., Ball, A., Pretty, J., 2008. Trends in pesticide use and drivers for safer pest management in four African countries. Crop Prot. 27, 1327-1334. 
Zhong, G., Liu, J. Weng, Q., Hu, M., Luo, J., 2006. Laboratory and field evaluations of rhodojaponin-III against the imported cabbage worm Pieris rapae (L. (Lepidoptera : Pieridae). Pest Manage Sci. 62, 976-981. 


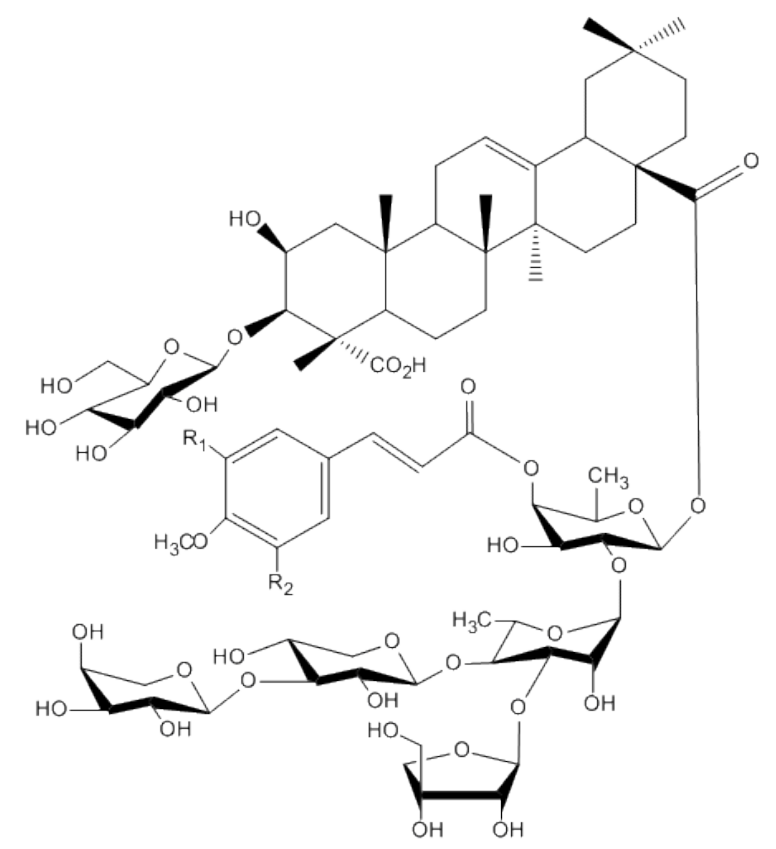

$$
\begin{gathered}
\mathrm{R}_{1}=\mathrm{R}_{2}=\mathrm{H} \text {; Securidacaside } \mathrm{A} \\
\mathrm{R}_{1}=\mathrm{R}_{2}=\mathrm{OCH}_{3} \text {; Securidacaside B }
\end{gathered}
$$

Figure 1. Insecticidal saponins from Securidaca longepedunculata root bark extracts 


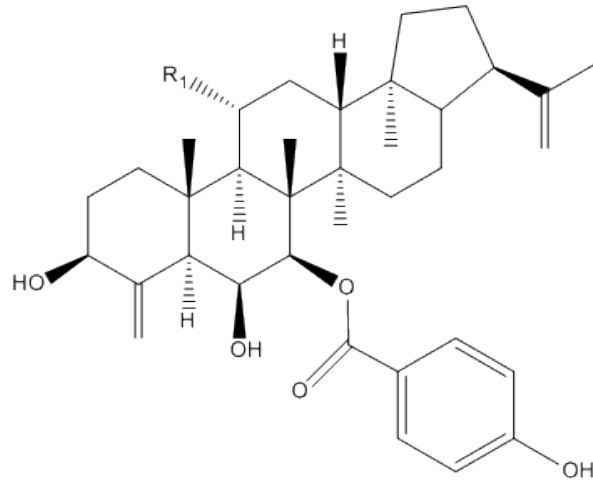

1

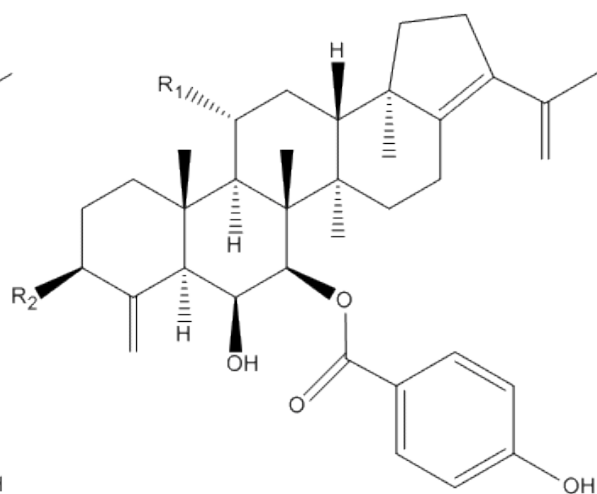

2

Figure 2. Two insecticidal terpenoids from Zanha africana root bark extracts $(\mathrm{R} 1=\mathrm{H}$, $3 \beta, 6 \beta$-dihydroxy-7 $\beta$-[(4-hydroxybenzoyl)oxy]-21 $\alpha \mathrm{H}$-24-norhopa-4(23),22(29)-diene (1) and

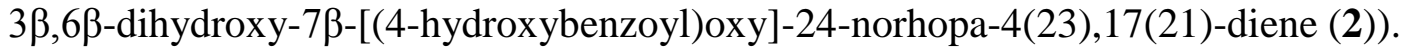




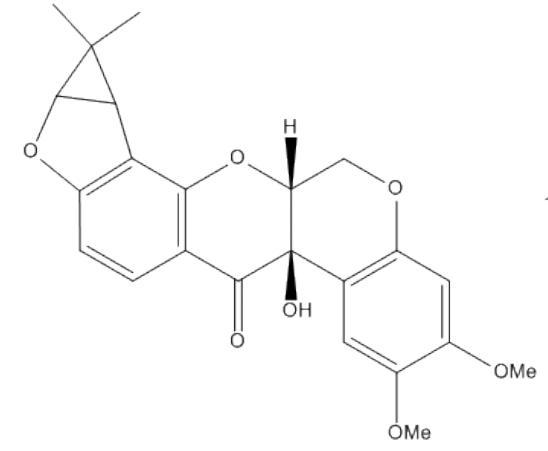

Chemtoype 1

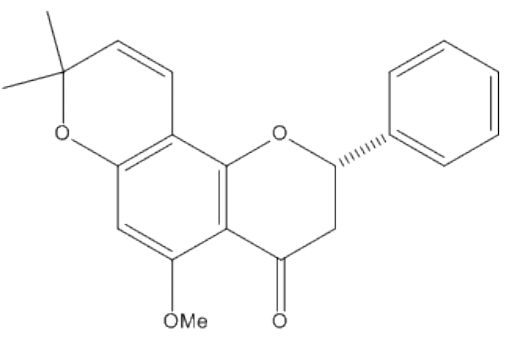

Chemotype 2

Fig 3. Two chemotypes of Tephrosia vogelii can be distinguished chemically based on the occurrence of entomotoxic rotenoids or inactive flavanones in their leaves. 
Table 1. Selected African Pesticidal Plants, their bioactive components and example target pest species.

\begin{tabular}{|c|c|c|c|c|c|}
\hline Plant species & $\begin{array}{l}\text { Compounds with } \\
\text { insecticidal activity }\end{array}$ & $\begin{array}{l}\text { Target pest species } \\
\text { reported }\end{array}$ & $\begin{array}{l}\text { Bioactive } \\
\text { plant part }\end{array}$ & Additional notes & Selected References \\
\hline Ageratum conyzoides & Cromenes & $\begin{array}{l}\text { Aphids and field pests of } \\
\text { beans }\end{array}$ & $\begin{array}{l}\text { Flowers, all } \\
\text { parts }\end{array}$ & Exotic weed & Rioba et al. 2017, Mkindi et al. 2017; \\
\hline Bidens pillosa & $\begin{array}{l}\text { Essential oils specific } \\
\text { compounds undetermined }\end{array}$ & Field pests of beans & Whole plant & Exotic weed & $\begin{array}{l}\text { Mkindi et al., 2017; Verma et al., } \\
2016\end{array}$ \\
\hline $\begin{array}{l}\text { Bobgunnia } \\
\text { madagascariensis }\end{array}$ & Saponins & Snails and Bruchidae & Pods & Sustainably harvestable pod & $\begin{array}{l}\text { Stevenson et al., 2010; Burkjhill } \\
\text { 1995; Borel and Hostettmann, } 1987\end{array}$ \\
\hline Cymbopogon spp. & Essential oils & $\begin{array}{l}\text { Mosquitoes, storage pests } \\
\text { Phlebotomus spp. }\end{array}$ & Whole plant & Easily cultivated & $\begin{array}{l}\text { Bossou et al., 2013; Stella-Nerio et } \\
\text { al., 2010; Kimutai et al., } 2017 .\end{array}$ \\
\hline Dysphania ambrosiodies & Ascaridole & Anopheles spp. & Whole plant & $\begin{array}{l}\text { Exotic weed (syn. } \\
\text { Chenopodium) }\end{array}$ & Boussou et al., 2013 \\
\hline Euphorbia tirucalli & $\begin{array}{l}\text { Latex specific compounds } \\
\text { not determined vs. insects }\end{array}$ & Anopheles spp. & Leaves & Irritant on skin & Mwine et al., 2010 \\
\hline Lippia javanica & $\begin{array}{l}\text { Ipsdienone, limonene, } \\
\text { perrilaldehyde }\end{array}$ & $\begin{array}{l}\text { Anopheles arabiensis, } \\
\text { Sitophilus zeamais }\end{array}$ & Whole plant & $\begin{array}{l}\text { Occurs as two botanical } \\
\text { varieties }\end{array}$ & $\begin{array}{l}\text { Muvundza et al., 2013. Kamanula et } \\
\text { al., } 2017\end{array}$ \\
\hline Melia volkensii & Triterpenoids & Trichoplusia ni & Seed kernels & $\begin{array}{l}\text { Underexploited indigenous } \\
\text { tree species }\end{array}$ & Akhtar et al., 2008. \\
\hline Neorautanenia mitis & Rotenoids, & $\begin{array}{l}\text { Anopheles gambiae, } \\
\text { Culex quinquefaciatus }\end{array}$ & Root tuber & $\begin{array}{l}\text { Mammalian toxicity but } \\
\text { also fed to cattle }\end{array}$ & Joseph et al. 2004. \\
\hline $\begin{array}{l}\text { Securidaca } \\
\text { longepedunculata }\end{array}$ & $\begin{array}{l}\text { Saponins and } \\
\text { methylsalicyclate }\end{array}$ & $\begin{array}{l}\text { Sitophilus spp. } \\
\text { Rhizopertha, Bruchidae }\end{array}$ & Root bark & Can be propagated & $\begin{array}{l}\text { Stevenson et al. 2009; Jayasekera et } \\
\text { al. 2002; Bossou et al., } 2013\end{array}$ \\
\hline $\begin{array}{l}\text { Solanum incanum (syn. } \\
\text { panduriforme) }\end{array}$ & $\begin{array}{l}\text { Not reported from } \\
\text { invertebrates }\end{array}$ & Termites, Boophilus spp. & Fruit dry & Mammalian toxicity & $\begin{array}{l}\text { Elsayed 2011, Madzimure et al., } \\
\text { 2013. Nyahangare et al. } 2012 .\end{array}$ \\
\hline Tagetes minuta & $\begin{array}{l}\text { Essential oils and } \\
\text { theophenes }\end{array}$ & $\begin{array}{l}\text { Phlebotomine flies, } \\
\text { Mosquitoes. }\end{array}$ & Whole plant & Exotic invasive weed & $\begin{array}{l}\text { Kimutai et al., 2017. Perich et al., } \\
1995\end{array}$ \\
\hline Tephrosia vogelii & $\begin{array}{l}\text { Tephrosin, deguelin, } \\
\text { rotenone }\end{array}$ & Bruchidae and Aphids & $\begin{array}{l}\text { All plant } \\
\text { parts }\end{array}$ & Toxicity vs vertebrates & $\begin{array}{l}\text { Stevenson et al., 2012; Belmain et } \\
\text { al., 2012. Mkindi et al. } 2017 .\end{array}$ \\
\hline Tithonia diversifolia & $\begin{array}{l}\text { Sesquiterpenes (Tagitinin } \\
\text { A and C) }\end{array}$ & $\begin{array}{l}\text { Bruchidae and field bean } \\
\text { pests }\end{array}$ & $\begin{array}{l}\text { Leaves and } \\
\text { flower buds }\end{array}$ & Exotic sp. notable weed & $\begin{array}{l}\text { Green et al., 2017; Mkindi et al., } \\
2017 .\end{array}$ \\
\hline Trichilia emetica & Triterpenoids & Anopheles arabiensis & Seeds & $\begin{array}{l}\text { Potential bi-product from } \\
\text { cosmetic industry. }\end{array}$ & Mavundza et al. 2013 \\
\hline Vernonia amygdalina & Sesquiterpenes & $\begin{array}{l}\text { Bruchidae and field bean } \\
\text { pests }\end{array}$ & Leaves & $\begin{array}{l}\text { Eaten as vegetable in Africa } \\
\text { indicating low toxicity }\end{array}$ & $\begin{array}{l}\text { Mkindi et al. 2017; Green et al., } \\
2017 .\end{array}$ \\
\hline Zanha africana & nor-Hopanes & Callosobruchus macultus & Root bark & $\begin{array}{l}\text { Roots used so requires } \\
\text { propagation }\end{array}$ & Stevenson et al. 2016 \\
\hline
\end{tabular}

